\title{
Proximate Composition and Mineral Contents of Farmed and Wild Fish in Kenya
}

\author{
Jennifer K. Raymond ${ }^{1}$, Arnold N. Onyango ${ }^{1}$ \& Christine A. Onyango ${ }^{1,2}$ \\ ${ }^{1}$ School of Food and Nutrition Sciences, Jomo Kenyatta University of Agriculture and Technology, Kenya \\ ${ }^{2}$ Taita Taveta University, Kenya \\ Correspondence: Jennifer K. Raymond, School of Food and Nutrition Sciences, Jomo Kenyatta University of \\ Agriculture and Technology, P.O. Box 62000, Nairobi, Kenya. Tel: 254-714-788-477. E-mail: \\ jennykeji@gmail.com
}

Received: March 17, 2020

Accepted: April 21, $2020 \quad$ Online Published: May 17, 2020

doi:10.5539/jfr.v9n3p53

URL: https://doi.org/10.5539/jfr.v9n3p53

\begin{abstract}
The Kenyan government is promoting fish farming to boost fish supply and reduce rural poverty and malnutrition. This study was carried out to determine the differences between the chemical composition of wild and farmed fish particularly Nile tilapia (Oreochromis niloticus) and African Catfish (Claris gariepinus) species. Wild fish were obtained from City market Nairobi, while farmed fish were obtained from selected ponds in Sagana and Kamulu (Kenya). Proximate composition, mineral and heavy metal content of the fish were determined using standard methods of analysis. Farmed fish contained significantly higher moisture content than the wild fish. Protein content in wild fish ranged from $21.9-22.1 \%$ compared to $16.0-19.2 \%$ in farmed fish. Fat content in wild fish ranged from $3.0-3.8 \%$ compared to $1.9-4.8 \%$ in farmed fish and ash from $1.8-2.1 \%$ in wild compared to $1.1-1.5 \%$ in farmed fish. The concentration of minerals in wild fish ranged from $2.8-3.0$ $\mathrm{mg} / 100 \mathrm{~g}$ of iron, $5.5-5.6 \mathrm{mg} / 100 \mathrm{~g}$ zinc, and $39.9-43.8 \mathrm{mg} / 100 \mathrm{~g}$ calcium compared to the lower values of 1.9 $-2.4 \mathrm{mg} / 100 \mathrm{~g}$ of iron, $28.2-37.0 \mathrm{mg} / 100 \mathrm{~g}$ calcium and $4.3-5.0 \mathrm{mg} / 100 \mathrm{~g}$ zinc in farmed fish respectively. Unfortunately, the wild fish was found to contain significantly higher concentrations of heavy metals as compared to the farmed fish $(P<0.05)$. From the results, it was evident that wild fish were nutritionally superior to the farmed fish but, they also contained significantly higher levels of toxic heavy metals.
\end{abstract}

Keywords: wild fish, farmed fish, proximate composition, fatty acids, tilapia, catfish

\section{Introduction}

Fish is a very important source of nutrients, including proteins, minerals, vitamins, and unsaturated essential fatty acids (PUFAS) particularly omega-3. It plays an important role in decreasing the risk of coronary diseases, mild hypertension and preventing certain types of arrhythmias (Lorente-Cebrián, Costa, Navas-Carretero, Zabala, Martínez \& Moreno-Aliaga, 2013). Both wild fish from natural water bodies and farmed fish are widely consumed, and have been found to differ in their nutritional value and sensory characteristics (Fuentes, Fernández-Segovia, Serra \& Barat, 2010). Such differences have been mainly attributed to differences in feed types and availability (Jonsson \& Jonsson, 2014). Fish farming may be intensive, whereby all the required nutrients are supplied through commercial feeds in sufficient amounts; or non-intensive, whereby only part of the fish's nutritional requirements are supplied through feeds, while the rest comes from organisms growing in fish ponds. In Kenya, many of the fish farmers practice non-intensive fish farming, with variations in the types and amounts of feeds supplied.

Pollution of the environment, especially the aquatic environment with heavy metals such as lead, copper, zinc, mercury, chromium, and cadmium, has become a worldwide problem. These heavy metals have become normal constituents of most of the water environment, including fish (Wu, Cobbina, Mao, Xu, Zhang \& Yang, 2016). Fish are known to concentrate heavy metals mostly in the liver or muscles (flesh), the latter being of most concern to man because it is the main tissue consumed as food (Kaile \& Nyirenda, 2016). Therefore, people consuming large amounts of fish or aquatic foods from coastal areas associated with chemical industries are at high risk of heavy metals poisoning (Ahmed, Baki, Islam, Kundu, Habibullah-Al-Mamun, Sarkar \& Hossain, 2015). Farmed fish may also be exposed to heavy metals and other pollutants from the environment. 
This study was conducted to determine the nutrient and heavy metal contents of wild fish and farmed fish grown under different non-intensive feeding regimes.

\section{Materials and Methods}

\subsection{Study Area}

Sampling was carried out in Sagana in Kirinyaga, Kamulu, and Nairobi (city market), all in Kenya.

\subsection{Study Species}

The study species were Tilapia (Oreochromis niloticus) and African Catfish (Clarias gariepinus) (Figure 1).

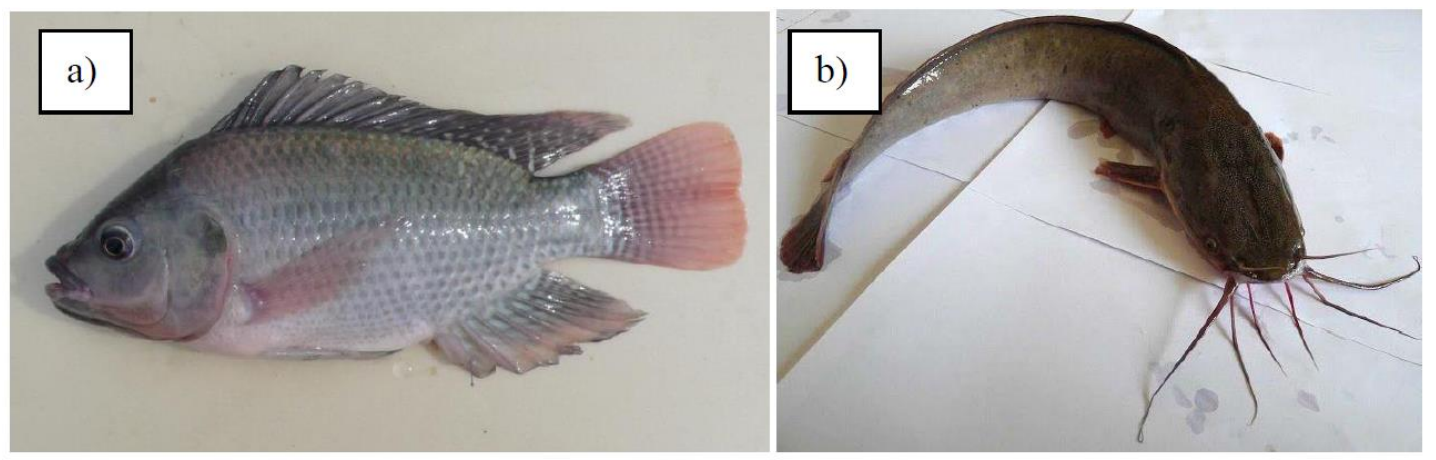

Figure 1. Pictures representing the study species of fish; (a) Oreochromis niloticus (Tilapia) (Source: CIRAD, Baroiller, 2012) (b) Clarias gariepinus (African Catfish) (Source: GOA, 2016)

\subsection{Sampling and Sample Collection}

The wild fish and farmed fish were sampled as shown in Table 1. The sampling was done four times during the study period, namely in January to April which represented the short rain season and April and May which represented the long rain season. Eight wild fish each of different weights; small fish (between $0.4-1.5 \mathrm{Kg}$ ) and big fish $(>1.5 \mathrm{Kg})$ were randomly purchased from vendors in city market as size may also influence the nutritional composition and heavy metal profile. This was done early in the morning when the fish had just arrived from Lake Victoria, and the sampling was done once every week during the four months of the study. On the other hand, farmed Tilapia and African catfish each of similar weight $(1 \mathrm{Kg})$ were purchased randomly from three farmers in Kirinyaga and Kamulu with different feeding systems (A, B, and C). Farm A feed consisted of Omena (Rastrineobola argentea) meal, mixed with lake shrimps (Caridina nilotica) meal and maize flour; farm $\mathrm{B}$ feed consisted of wheat bran mixed with cotton seed meal; and farm $\mathrm{C}$ feed consisted of chicken droplets and maize flour. Two farmers representing each feeding system were chosen. Sampling was done once every week during the four months of the sampling period. The wild and farmed fish were packed in cool boxes containing ice at approximately $4{ }^{\circ} \mathrm{C}$ and transported to the department of Food Science and Technology laboratory at Jomo Kenyatta University of Agriculture and Technology (JKUAT). They were then degutted, filleted and kept in freezer at $4{ }^{\circ} \mathrm{C}$ for analysis. 
Table 1. Sampling of the wild fish from city market Nairobi and farmed fish

\begin{tabular}{|c|c|c|c|c|c|}
\hline & & \multicolumn{4}{|l|}{ Wild fish } \\
\hline Month & & Week 1 & Week 2 & Week 3 & Week 4 \\
\hline \multirow[t]{2}{*}{1} & Big & 2tilapia+2catfish & 2tilapia+2catfish & 2tilapia+2catfish & 2tilapia+2catfish \\
\hline & Small & 2tilapia+2catfish & 2tilapia+2catfish & 2tilapia+2catfish & 2tilapia+2catfish \\
\hline \multirow[t]{2}{*}{2} & Big & 2tilapia+2catfish & 2tilapia+2catfish & 2tilapia+2catfish & 2tilapia+2catfish \\
\hline & Small & 2tilapia+2catfish & 2tilapia+2catfish & 2tilapia+2catfish & 2tilapia+2catfish \\
\hline \multirow[t]{2}{*}{3} & Big & 2tilapia+2catfish & 2tilapia+2catfish & 2tilapia+2catfish & 2tilapia+2catfish \\
\hline & Small & 2tilapia+2catfish & 2tilapia+2catfish & 2tilapia+2catfish & 2tilapia+2catfish \\
\hline \multirow[t]{2}{*}{4} & Big & 2tilapia+2catfish & 2tilapia+2catfish & 2tilapia+2catfish & 2tilapia+2catfish \\
\hline & Small & 2tilapia+2catfish & 2tilapia+2catfish & 2tilapia+2catfish & 2tilapia+2catfish \\
\hline \multirow[t]{3}{*}{1} & A & 3tilapia+3catfish & 3tilapia+3catfish & 3tilapia+3catfish & 3tilapia+3catfish \\
\hline & B & 3tilapia+3catfish & 3tilapia+3catfish & 3tilapia+3catfish & 3tilapia+3catfish \\
\hline & $\mathrm{C}$ & 3tilapia+3catfish & 3tilapia+3catfish & 3tilapia+3catfish & 3tilapia+3catfish \\
\hline \multirow[t]{3}{*}{2} & A & 3tilapia+3catfish & 3tilapia+3catfish & 3tilapia+3catfish & 3tilapia+3catfish \\
\hline & B & 3tilapia+3catfish & 3tilapia+3catfish & 3tilapia+3catfish & 3tilapia+3catfish \\
\hline & $\mathrm{C}$ & 3tilapia+3catfish & 3tilapia+3catfish & 3tilapia+3catfish & 3tilapia+3catfish \\
\hline \multirow[t]{3}{*}{3} & A & 3tilapia+3catfish & 3tilapia+3catfish & 3tilapia+3catfish & 3tilapia+3catfish \\
\hline & B & 3tilapia+3catfish & 3tilapia+3catfish & 3tilapia+3catfish & 3tilapia+3catfish \\
\hline & $\mathrm{C}$ & 3tilapia+3catfish & 3tilapia+3catfish & 3tilapia+3catfish & 3tilapia+3catfish \\
\hline \multirow[t]{3}{*}{4} & A & 3tilapia+3catfish & 3tilapia+3catfish & 3tilapia+3catfish & 3tilapia+3catfish \\
\hline & B & 3tilapia+3catfish & 3tilapia+3catfish & 3tilapia+3catfish & 3tilapia+3catfish \\
\hline & $\mathrm{C}$ & 3tilapia+3catfish & 3 tilapia +3 catfish & 3tilapia+3catfish & 3 tilapia+3catfish \\
\hline
\end{tabular}

\subsection{Sample Preparation and Analysis}

The fillet were minced and analyzed for moisture, ash contents, protein, lipid content, mineral composition and heavy metal content.

\subsubsection{Proximate Composition of Fish}

Analyses of fish samples for moisture, ash, crude protein and lipid contents were carried out in triplicates according to the standard AOAC methods (AOAC, 2006). Moisture content was determined using oven drying method at $105{ }^{\circ} \mathrm{C}$ to constant weight whereas ash content was determined by incineration of the dried fish sample in a muffle furnace at $550-600{ }^{\circ} \mathrm{C}$ for 6 hours (AOAC 920.153). Crude protein was determined by estimating the nitrogen content $(\%$ protein $=\mathrm{N} \times 6.25)$ of the fish samples using the micro-Kjeldahl procedure (AOAC 928.08), while total fat was determined by Soxhlet extraction using methanol-chloroform solvent (2:1 v/v) (AOAC 991.36).

\subsubsection{Mineral and Heavy Metals Determinations}

For minerals analysis $(\mathrm{Mg}, \mathrm{Fe}, \mathrm{Mn}, \mathrm{Cu}, \mathrm{Zn})$ the ash samples were digested with $2.5 \mathrm{ml} \mathrm{HNO}_{3}$ and $60 \%$ perchloric acids according to AOAC method (2006). The digested samples were used for selected minerals analysis, using atomic absorption spectrophotometer (Model A A-6200, Shimadzu, Corp., Kyoto, Japan). Heavy metals $(\mathrm{Hg}, \mathrm{Pb}, \mathrm{Cr}, \mathrm{Cd})$ were also determined by AAS. Two grams from the ash sample were placed in a digestion tube and pre-digested using $10 \mathrm{ml}$ of $\mathrm{HNO}_{3}$ and $1 \mathrm{ml}$ of $\mathrm{HClO}_{3}$ acids were added and temperature maintained at $135^{\circ} \mathrm{C}$ until the liquor was colorless. The digested liquors were then filtered through a whatman 1 filter paper and diluted to $25 \mathrm{ml}$ with distilled water. Suitable standard solutions were prepared and their absorbance measured to prepare a standard curve. The standard curve was used to calculate the concentration of minerals.

\subsection{Data Analysis}

To determine compositional differences between fish from different sources, data were subjected to analysis of variance (ANOVA) using the statistical analysis system SAS as outlined by Wahwua (1999) and McHugh (2011).

\section{Results and Discussion}

\subsection{Proximate Composition}

The proximate composition results of the wild and farmed fish are presented in Table 2. The moisture contents ranged between $70.9-78.1 \%$. The farmed fish had significantly higher moisture content as compared with the 
wild fish $(P<0.05)$. The farmed tilapia had moisture content ranging between $75.2-78.1 \%$ whereas the wild tilapia had the moisture content between $71.2-73.1 \%$. The farmed catfish on the other hand, had moisture content ranging from 73.8 - $77.3 \%$ whereas the wild counterparts had moisture content ranging from 70.9 $72.4 \%$. Therefore from the results, it is evident that both the farmed and wild tilapia fish had slightly higher moisture content as compared to the catfish. Feeding systems also influenced moisture content, as fish from system B and C had significantly higher moisture content than those from feeding system A. Moreover, it was observed that the moisture content of the wild fish decreased with increasing body weight with the small catfish and tilapia reporting $72.4 \%$ and $73.1 \%$, respectively while the large catfish and tilapia having $70.9 \%$ and $71.2 \%$, respectively. Since feeding system A had higher dietary protein, the findings of the present study concur with other studies which reported that in fish muscle, moisture and ash contents decrease with an increase in fats and protein contents and vice versa (Mahboob, Al-Ghanim, Al-Balawi, Al-Misned, \& Ahmed, 2019; Jim, Garamumhango \& Musara, 2017) and that increased water content is due to decreasing fat and protein contents in the fish body (Mahboob et al., 2019; Jim et al., 2017). The lower moisture content in wild fish may additionally be attributed to more physical efforts performed by the wild fish species to capture food organisms in the natural habitat than the farmed fish which has plenty of food supply in the ponds (Jim et al., 2017).

The ash content of fish ranged between $1.2-2.1 \%$ with the wild fish reporting significantly higher contents as compared to the farmed fish $(P<0.05)$. The farmed tilapia and catfish had ash content ranging from $1.2-1.4 \%$ and $1.3-1.5 \%$ respectively, whereas the wild counterparts had ash contents ranging from $1.8-1.9 \%$ and 1.9 $2.1 \%$, respectively. For the wild fish, big tilapia and catfish had significantly higher ash contents of $1.9 \%$ and $2.1 \%$ as compared to the small fish with values of $1.8 \%$ and $1.9 \%$, respectively. However, there was no significant difference between the ash content of the fish from the three feeding systems. These results concur with the findings by Bhouri and colleagues (2010) which reported an increase in ash content in wild fish as compared to the farmed fish. The observed range of ash content in this study indicated that the species is a good source of minerals since ash is a measure of the mineral content of food item (Oladipo \& Bankole, 2013).

Protein content ranged from $16.0-22.1 \%$. From the results, it was evident that wild fish had significantly higher protein content $(20.2-22.1 \%)$ than farmed fish $(16.0-19.2 \%)$. Farmed catfish had protein content ranging from $16.3-19.2 \%$ as compared to $21.0-22.1 \%$ for the wild type. The farmed tilapia on the other hand, had protein content ranging from $16.0-18.9 \%$, while the wild counterparts had the content ranging from $20.2-$ $22.0 \%$. For the different feeding systems, feeding system A reported significantly higher contents of protein as compared to the other two feeding systems B and $\mathrm{C}(P<0.05)$. However, there was no significant difference between feeding system $\mathrm{B}$ and $\mathrm{C}(P>0.05)$. The high protein content in feeding system A may be attributed to the diet which comprised of omena and lake shrimps which are richer in proteins. For the wild fish, the big tilapia and catfish reported significantly higher protein content of $21.9 \%$ and $22.1 \%$ respectively as compared to the small tilapia and catfish with protein values of $20.2 \%$ and $20.8 \%$, respectively.

The fat content of the fish ranged from $1.9-4.9 \%$. The content of farmed tilapia and catfish ranged from $1.9-$ $4.8 \%$ and $2.0-4.9 \%$, respectively, while for the wild tilapia and catfish ranged from $3.0-3.4 \%$ and $3.1-3.8 \%$, respectively. There was no significant difference in the fat content of fish from feeding system A and wild fish. On the other hand, feeding systems B had higher fat contents than farmed fish from feeding system A whereas feeding systems $\mathrm{C}$ had lower fat contents than $\mathrm{A}$. The higher fat content in feeding system B was expected as it contained wheat bran and cotton seed which are rich in fats. For the wild fish, the big fish had slightly higher fat content than small fish.

The results of this study concurs with the findings of a study by Adebayo, Fapohunda, \& Ajibade, (2016) which reported that catfish contain slightly higher ash, fat and protein contents than the tilapia. In addition, it confirms that proximate composition of farmed fish is directly influenced by their diet. According to Fuentes et al. (2010) and Rani, Kumar, Rao, \& Shameem, (2016), the variation in proximate composition of fish is as a result of differences in nutrition, living area, fish size, catching season, seasonal and sexual variations as well as other environmental conditions. Furthermore, the results indicate that the wild fish is richer in most of the nutrients than the farmed fish from the three non-intensive feeding systems used by farmers in Kenya. The results corroborate the findings of other studies which compared the composition of wild and farmed fish (Job, Antai, Inyang-Etoh, Otogo, \& Ezekiel, 2015). According to these studies, the proximate composition differed based on the type of food and habitat of the fish. 
Table 2. Proximate composition

\begin{tabular}{|c|c|c|c|c|c|c|c|}
\hline \multirow{2}{*}{\multicolumn{2}{|c|}{ Feeding system }} & \multirow[t]{2}{*}{ Fish type } & \multirow[t]{2}{*}{ Sample size } & \multicolumn{4}{|c|}{ Percentage proximate composition } \\
\hline & & & & Moisture & Ash & Fat & Protein \\
\hline \multirow[t]{6}{*}{ Farm } & \multirow[t]{2}{*}{ A } & Catfish & 24 & $73.8^{b} \pm 0.62$ & $1.5^{\mathrm{c}} \pm 0.09$ & $3.5^{\mathrm{b}} \pm 0.09$ & $19.2^{c} \pm 0.65$ \\
\hline & & Tilapia & 40 & $75.2^{\mathrm{b}} \pm 1.12$ & $1.4^{\mathrm{c}} \pm 0.21$ & $3.4^{\mathrm{b}} \pm 0.39$ & $18.9^{\mathrm{c}} \pm 1.44$ \\
\hline & \multirow[t]{2}{*}{ B } & Catfish & 24 & $76.1^{\mathrm{a}} \pm 1.01$ & $1.4^{\mathrm{c}} \pm 0.02$ & $4.9^{\mathrm{a}} \pm 0.17$ & $16.9^{\mathrm{d}} \pm 1.29$ \\
\hline & & Tilapia & 40 & $76.3^{\mathrm{a}} \pm 1.72$ & $1.3^{\mathrm{c}} \pm 0.06$ & $4.8^{\mathrm{a}} \pm 0.25$ & $16.6^{\mathrm{d}} \pm 0.92$ \\
\hline & \multirow[t]{2}{*}{$\mathrm{C}$} & Catfish & 24 & $77.3^{\mathrm{a}} \pm 1.19$ & $1.3^{\mathrm{c}} \pm 0.12$ & $2.0^{c} \pm 0.58$ & $16.3^{\mathrm{d}} \pm 2.03$ \\
\hline & & Tilapia & 40 & $78.1^{\mathrm{a}} \pm 0.92$ & $1.2^{\mathrm{c}} \pm 0.16$ & $1.9^{c} \pm 0.17$ & $16.0^{\mathrm{d}} \pm 1.76$ \\
\hline \multirow[t]{4}{*}{ Wild } & \multirow[t]{2}{*}{ Big fish } & Catfish & 16 & $70.9^{c} \pm 1.74$ & $2.1^{\mathrm{a}} \pm 0.19$ & $3.8^{\mathrm{b}} \pm 0.33$ & $22.1^{\mathrm{a}} \pm 0.96$ \\
\hline & & Tilapia & 16 & $71.2^{\mathrm{c}} \pm 1.06$ & $1.9^{\mathrm{a}} \pm 0.17$ & $3.4^{\mathrm{b}} \pm 0.37$ & $21.9^{\mathrm{a}} \pm 1.57$ \\
\hline & \multirow[t]{2}{*}{ Small fish } & Catfish & 16 & $72.4^{\mathrm{c}} \pm 1.14$ & $1.9^{\mathrm{b}} \pm 0.30$ & $3.1^{\mathrm{b}} \pm 0.26$ & $21.0^{\mathrm{b}} \pm 1.07$ \\
\hline & & Tilapia & 16 & $73.1^{c} \pm 0.38$ & $1.8^{\mathrm{b}} \pm 0.21$ & $3.0^{\mathrm{b}} \pm 0.15$ & $20.2^{\mathrm{b}} \pm 1.48$ \\
\hline
\end{tabular}

* Values are given as means \pm Std dev. Means with different superscript letters within a column are significantly different $(\mathrm{P}<0.05)$.

\subsection{Mineral Composition}

The results for the mineral composition of the two fish are shown in Table 3. All the fish samples examined contained appreciable concentrations of calcium, zinc, magnesium, phosphorus and iron suggesting that these fish could be used as good sources of minerals. The data revealed wide variations in the mineral contents of the wild and farmed fish. The concentrations ranged from $1.9-3.0 \mathrm{mg} / 100 \mathrm{~g}$ for iron, $4.3-5.6 \mathrm{mg} / 100 \mathrm{~g}$ for zinc, 21.2 - $30.9 \mathrm{mg} / 100 \mathrm{~g}$ for phosphorus, 28.2 - $46.8 \mathrm{mg} / 100 \mathrm{~g}$ for calcium, $106.1-137.2 \mathrm{mg} / 100 \mathrm{~g}$ for magnesium and $0.4-0.7 \mathrm{mg} / 100 \mathrm{~g}$ for copper.

Wild fish were found to contain significantly higher concentrations of all the minerals than the farmed fish (P< 0.05). However, there was no significant difference between the mineral contents of the big and small fish from the wild habitats. On the other hand, there were no significant differences in $\mathrm{Mg}, \mathrm{P}$, and $\mathrm{Zn}$ in fish from feeding systems A, B and C. Although the mineral content of big catfish was slightly higher than that of big tilapia, the opposite was true for the small catfish and tilapia. In addition, there was no significant difference between the tilapia and catfish.

Magnesium content ranged from 129.2 - $137.2 \mathrm{mg} / 100 \mathrm{~g}$ for wild fish and $106.1-126.0 \mathrm{mg} / 100 \mathrm{~g}$ for the farmed fish. The copper content of the wild fish was significantly higher with values ranging from $0.6-0.7 \mathrm{mg} / 100 \mathrm{~g}$ as compared to the farmed fish with ranges of $0.4-0.5 \mathrm{mg} / 100 \mathrm{~g}$. For the farmed fish, feeding system A gave higher contents of calcium as compared to other feeding systems, while tilapia from system B had lower iron levels than the rest. Tilapia fish in the farms $\mathrm{A}$ and $\mathrm{C}$ contained slightly higher mineral content compared to catfish. This is contrary to farm B where tilapia reported slightly lower levels of minerals than the catfish. The reason for such differences in mineral uptake by catfish and tilapia in different feeding systems is not clear.

Generally, similar ranges of mineral contents reported in this study have been reported by FAO (2010) and USDA (2010) permissible limits for fish. The findings of this study are comparable with the finding of Adebayo et al. (2016) which reported calcium $(6-825 \mathrm{mg} / 100 \mathrm{~g})$, zinc $(1-12 \mathrm{mg} / 100 \mathrm{~g})$ and phosphorous $(10-82$ $\mathrm{mg} / 100 \mathrm{~g}$ ). In contrast the magnesium content from this study was higher than the contents $4-12 \mathrm{mg} / 100 \mathrm{~g}$ reported by Adebayo et al. (2016). On the other hand, iron content from the study was lower as compared to the $3-102 \mathrm{mg} / 100 \mathrm{~g}$ observed by Adebayo et al. (2016). The variations recorded in the concentration of mineral in fish examined could be as a result of the rate in which they are available in the water body. Alasalvar, Taylor, Zubcov, Shahidi, \& Alexis, (2002) and El-Zaeem, El-Tawil, \& Amer, (2012) reported that mineral concentration of fish is affected by parameters such as feed type, level of dietary intake and growth. According to PfenningKurth, Meißner, Standke, Hoppe, Zieschang, \& Gutzeit, (2011), the wild fish feed on a wide diversity of microscopic organisms and macrophytes which may be lacking in controlled farmed systems. Therefore the feed composition of the farmed fish may also be major factor influencing their mineral content as reported by El-zaeem et al. (2012).

The minerals analyzed in this study are known to be important in human health. Therefore the high concentration of minerals in the wild fish is advantageous since they are known to intervene in therapeutic aspects. Calcium is required as a component of the human diet, and it is essential for the full activity of many enzymes, such as nitric oxide synthase, protein phosphatases, and adenylate kinase. It is also necessary to maintain an optimal bone 
development (Beto, 2015). Besides, calcium is also good for growth and maintenance of bones, teeth and muscles (Pravina, Sayaji, \& Avinash, 2013). Normal extra cellular calcium concentrations are necessary for blood coagulation and for the integrity, intracellular cement substances (Mohanty et al., 2019).

Magnesium is an essential mineral for cell function as it acts as a co-factor of pyruvate dehydrogenase, an enzyme which transforms pyruvate into acetyl-CoA used in the citric acid cycle to carry out cellular respiration to release energy. The recommended daily allowance (RDA) for $\mathrm{Mg}$ is $2000 \mathrm{mg}$ per day for a healthy adult (Lenntech, 2013). Phosphorus is also an important mineral as it has been reported to form the structure of teeth, bones and cell membranes (Butusov \& Jernelöv, 2013). It also acts as a cofactor for many enzymes and activates the vitamin B complex.

Other elements such as zinc and iron varied in concentration among all the fish studied. These elements are equally important in trace amounts as observed, but they tend to become harmful when their concentrations in the tissues exceed the metabolic demands (Adebayo et al., 2016). Zinc is an essential element in human diet as it plays an important role in maintenance of normal glucose tolerance and in the release of insulin from beta cells of islets of Langerhans (Piero, Njagi, Kibiti, Ngeranwa, Njagi, \& Miriti, 2012; Praveeena, PaSula, \& Sameera, 2013). Therefore the availability of zinc in fish could mean that the fishes can play valuable roles in the management of diabetes, which result from insulin malfunction. In addition, it is involved in most metabolic pathways in animals and humans (FAO, 2010).

Iron on the other hand, is important for metabolic reactions and the regulation of cell growth and differentiation. It is an essential trace element for haemoglobin formation, normal functioning of the central nervous system and in the oxidation of carbohydrates, protein and fats. Iron is important for children, women of reproductive age and pregnant women since they are most vulnerable to micronutrient deficiency and anemia (WHO, 2015). Iron deficiency occurs when the demand for iron is high, particularly in growth, high menstrual loss and pregnancy and the intake is quantitatively inadequate for or contains elements that render them unavailable for absorption (Kumaran et al., 2012). Besides, iron acts as a cofactor in catalase, an enzyme that catalyzes the conversion of hydrogen peroxide to water and oxygen (Soetan, Olaiya, \& Oyewole, 2010). Iron and zinc are also antioxidant micronutrients and their presence could boost the immune system (Prashanth, Kattapagari, Chitturi, Baddam, \& Prasad, 2015). Since deficiencies in calcium, iron and zinc are common in the developing world, and are the leading cause of many ailments (Mohanty, Sankar, Ganguly, Mahanty, Anandan, Chakraborty, \& Asha, 2016) fish eating is encouraged as this may contribute to alleviation of this problem in the vulnerable groups.

Table 3. Mineral composition of farmed and wild fish

\begin{tabular}{|c|c|c|c|c|c|c|c|c|c|}
\hline \multicolumn{2}{|c|}{ Feeding system } & \multirow[t]{2}{*}{ Fish type } & \multirow{2}{*}{$\begin{array}{l}\text { Sample } \\
\text { size }(\mathrm{N})\end{array}$} & \multicolumn{6}{|c|}{ Mineral composition of fish sample $(\mathrm{mg} / 100 \mathrm{~g})$} \\
\hline & & & & Calcium & Iron & Magnesium & Phosphorus & Zinc & Copper \\
\hline \multirow[t]{6}{*}{ Farm } & \multirow{2}{*}{ A } & Catfish & 24 & $35.0^{\mathrm{b}} \pm 2.0$ & $2.4^{\mathrm{b}} \pm 0.1$ & $117.2^{\mathrm{b}} \pm 2.1$ & $25.0^{\mathrm{b}} \pm 1.8$ & $5.0^{\mathrm{b}} \pm 0.2$ & $0.48^{\mathrm{b}} \pm 0.07$ \\
\hline & & Tilapia & 40 & $37.0^{\mathrm{b}} \pm 1.0$ & $2.4^{\mathrm{b}} \pm 0.2$ & $124.2^{\mathrm{b}} \pm 1.3$ & $25.3^{\mathrm{b}} \pm 1.1$ & $4.4^{\mathrm{b}} \pm 0.5$ & $0.44^{\mathrm{b}} \pm 0.01$ \\
\hline & \multirow{2}{*}{ B } & Catfish & 24 & $34.1^{\mathrm{b}} \pm 1.3$ & $2.3^{\mathrm{b}} \pm 0.1$ & $126.0^{\mathrm{b}} \pm 1.9$ & $24.2^{\mathrm{b}} \pm 1.8$ & $4.8^{\mathrm{b}} \pm 0.4$ & $0.39^{c} \pm 0.04$ \\
\hline & & Tilapia & 40 & $31.5^{\mathrm{c}} \pm 1.8$ & $1.9^{\mathrm{c}} \pm 0.1$ & $112.1^{\mathrm{b}} \pm 2.7$ & $21.2^{\mathrm{b}} \pm 0.4$ & $4.6^{\mathrm{b}} \pm 0.6$ & $0.42^{\mathrm{b}} \pm 0.02$ \\
\hline & \multirow{2}{*}{$\mathrm{C}$} & Catfish & 24 & $28.2^{\mathrm{c}} \pm 2.0$ & $2.2^{\mathrm{b}} \pm 0.2$ & $106.1^{\mathrm{b}} \pm 7.2$ & $23.2^{\mathrm{b}} \pm 0.4$ & $4.3^{\mathrm{b}} \pm 0.5$ & $0.35^{\mathrm{c}} \pm 0.07$ \\
\hline & & Tilapia & 40 & $30.2^{\mathrm{c}} \pm 1.2$ & $2.2^{\mathrm{b}} \pm 0.3$ & $118.2^{\mathrm{b}} \pm 2.3$ & $24.4^{\mathrm{b}} \pm 0.9$ & $4.4^{\mathrm{b}} \pm 0.3$ & $0.44^{\mathrm{b}} \pm 0.03$ \\
\hline \multirow[t]{4}{*}{ Wild } & Big & Catfish & 16 & $43.8^{\mathrm{a}} \pm 2.2$ & $3.0^{\mathrm{a}} \pm 0.6$ & $134.2^{\mathrm{a}} \pm 4.3$ & $29.5^{\mathrm{a}} \pm 1.5$ & $5.5^{\mathrm{a}} \pm 0.8$ & $0.59^{\mathrm{a}} \pm 0.02$ \\
\hline & fish & Tilapia & 16 & $39.9^{\mathrm{a}} \pm 2.2$ & $2.8^{\mathrm{a}} \pm 0.2$ & $129.2^{\mathrm{a}} \pm 7.1$ & $28.3^{\mathrm{a}} \pm 1.1$ & $5.4^{\mathrm{a}} \pm 0.8$ & $0.55^{\mathrm{a}} \pm 0.09$ \\
\hline & Small & Catfish & 16 & $42.4^{\mathrm{a}} \pm 1.1$ & $2.8^{\mathrm{a}} \pm 0.4$ & $131.3^{\mathrm{a}} \pm 3.9$ & $30.4^{\mathrm{a}} \pm 2.1$ & $5.3^{\mathrm{a}} \pm 0.9$ & $0.62^{\mathrm{a}} \pm 0.08$ \\
\hline & fish & Tilapia & 16 & $46.8^{\mathrm{a}} \pm 1.9$ & $3.0^{\mathrm{a}} \pm 0.1$ & $137.2^{\mathrm{a}} \pm 5.1$ & $30.9^{\mathrm{a}} \pm 1.9$ & $5.6^{\mathrm{a}} \pm 0.6$ & $0.69^{\mathrm{a}} \pm 0.04$ \\
\hline
\end{tabular}

* Values are given as means \pm Std dev. Means with different superscript letters within a column are significantly different $(\mathrm{P}<0.05)$.

\subsection{Heavy Metal Content}

The results for the heavy metal composition are presented in Table 4. The concentrations ranged from $0.1-0.3$ $\mathrm{mg} / 100 \mathrm{~g}$ for chromium, $0.3-0.7 \mathrm{mg} / 100 \mathrm{~g}$ for lead, $0.2-0.4 \mathrm{mg} / 100 \mathrm{~g}$ for cadmium and $11.9-17.6 \mu \mathrm{g} / 100 \mathrm{~g}$ for mercury. The heavy metal content of the wild fish was significantly higher with values ranging from $0.24-0.30$ $\mathrm{mg} / 100 \mathrm{~g}$ chromium, $0.5-0.7 \mathrm{mg} / 100 \mathrm{~g}$ lead, $0.3-0.4 \mathrm{mg} / 100 \mathrm{~g}$ cadmium and $16.2-18.3 \mu \mathrm{g} / 100 \mathrm{~g}$ mercury as compared to the farmed fish with ranges of $0.13-0.23 \mathrm{mg} / 100 \mathrm{~g}$ chromium, $0.3-0.4 \mathrm{mg} / 100 \mathrm{~g}$ lead, $0.2-0.3$ $\mathrm{mg} / 100 \mathrm{~g}$ cadmium and $11.9-15.4 \mu \mathrm{g} / 100 \mathrm{~g}$ mercury. Although there was no significant difference between the values of the small and big fish from wild habitat, the big catfish reported slightly higher heavy metal contents as compared to the big tilapia. This was contrary to the small catfish which reported slightly lower heavy metal 
levels than the small tilapia fish. The high accumulation of heavy metals in wild fish as compared to farmed fish depends on its amount in water and sediments which act as the most important reservoir or sink of metals and other pollutants in the aquatic environment (Gupta, Rai, Pandey, \& Sharma, 2009; González-Fernández, Garrido-Pérez, Nebot-Sanz, \& Sales-Márquez, 2011). Heavy metal contamination in sediment can affect the water quality and bioaccumulation of metals in aquatic organisms, resulting in potential long-term implication on human health and ecosystem (González-Fernández et al., 2011).

For the farmed fish, feeding system A was significantly higher in heavy metal content as compared to the other feeding systems. On the other hand, farm B reported significantly lower heavy metal content. The tilapia fish from farm $\mathrm{A}$ and $\mathrm{C}$ reported slightly higher levels of heavy metals particularly chromium and lead whereas the tilapia fish from farm B reported lower levels. Heavy metals in system A may be at least partly derived from the $R$. argentea and $C$. nilotica components of the feed.

Lead had a higher content as compared to the other heavy metals whereas mercury reported lower levels. According to WHO (2011), the maximum allowable concentration for Pb and Cd were 200, 50 and $10000 \mathrm{ppb}$, respectively. However, such food limits are not defined to all the elements (Agah, Leermakers, Elskens, Fatemi, \& Baeyens, 2009). The element levels of fish muscles in this study were below the maximum allowable concentration suggested by WHO (2011) and have no threat to public health. Although, fish is the main source of mercury in human diet (Mania, Wojciechowska-Mazurek, Starska, Rebeniak, \& Postupolski, 2012), mercury was found to be the least accumulating metal during this study. The present study agrees with the results obtained by Bosch, O'Neill, Sigge, Kerwath, \& Hoffman, (2016) which found out that mercury is least accumulated in fish and is high in wild fish as compared to farmed fish. According to Perugini, Visciano, Manera, Zaccaroni, Olivieri, \& Amorena, (2014) the concentration of heavy metal contaminants in fish is strongly influenced by fish age, origin of the fish, its species and $\mathrm{pH}$ and temperature of water. It is also related to the tissue sampled, the season of harvest especially for farmed fish, and the composition of the diet (Hussain, Muhammad, Malik, Khan, \& Farooq, 2014). The health and safety qualities of fish is an advantage to the fish farming industry owing to the fact that, unlike fishermen, fish farmers can control for the presence of toxic contaminants and pathogens in their fish throughout the production process. Whereas the diet of wild fish is totally beyond human control, the development of formulated diets, which are used in aquaculture, makes it possible to directly control contaminant levels (Craig, Helfrich, Kuhn, \& Schwarz, 2017; Davidson, Barrows, Kenney, Good, Schroyer, \& Summerfelt, 2016).

Table 4. Heavy metal composition of farmed and wild fish

\begin{tabular}{|c|c|c|c|c|c|c|c|}
\hline \multicolumn{2}{|c|}{ Feeding } & Fish & Sample size & Chromium & Lead & Cadmium & Mercury \\
\hline \multirow[t]{6}{*}{ Farm } & $\mathrm{A}$ & Catfish & 24 & $0.20^{\mathrm{b}} \pm 0.05$ & $0.39^{\mathrm{b}} \pm 0.06$ & $0.28^{\mathrm{b}} \pm 0.04$ & $15.2^{\mathrm{b}} \pm 1.7$ \\
\hline & & Tilapia & 40 & $0.23^{\mathrm{a}} \pm 0.01$ & $0.42^{\mathrm{b}} \pm 0.05$ & $0.23^{\mathrm{c}} \pm 0.02$ & $15.4^{\mathrm{b}} \pm 1.7$ \\
\hline & B & Catfish & 24 & $0.17^{\mathrm{c}} \pm 0.06$ & $0.36^{\mathrm{b}} \pm 0.01$ & $0.24^{\mathrm{c}} \pm 0.02$ & $11.9^{\mathrm{c}} \pm 1.0$ \\
\hline & & Tila & 40 & $0.13^{\mathrm{c}} \pm 0.02$ & $0.31^{\mathrm{c}} \pm 0.04$ & $0.21^{\mathrm{c}} \pm 0.06$ & $13.5^{\mathrm{c}} \pm 1.1$ \\
\hline & $\mathrm{C}$ & Catfish & 24 & $0.14^{\mathrm{c}} \pm 0.05$ & $0.34^{\mathrm{c}} \pm 0.05$ & $0.26^{\mathrm{b}} \pm 0.02$ & $12.6^{\mathrm{b}} \pm 0.7$ \\
\hline & & $\mathrm{Ti}$ & 40 & $0.19^{\mathrm{b}} \pm 0.09$ & $0.37^{b} \pm 0.09$ & $0.27^{b} \pm 0.01$ & $14.8^{b} \pm 0.9$ \\
\hline \multirow[t]{4}{*}{ Wild } & Big fish & Catfish & 16 & $0.27^{\mathrm{a}} \pm 0.07$ & $0.58^{\mathrm{a}} \pm 0.04$ & $0.34^{\mathrm{a}} \pm 0.05$ & $17.6^{\mathrm{a}} \pm 1.5$ \\
\hline & & Tila & 16 & $0.24^{\mathrm{a}} \pm 0.07$ & $0.52^{\mathrm{a}} \pm 0.03$ & $0.33^{\mathrm{a}} \pm 0.04$ & $18.3^{\mathrm{a}} \pm 2.5$ \\
\hline & Small fish & Catfish & 16 & $0.26^{\mathrm{a}} \pm 0.03$ & $0.61^{\mathrm{a}} \pm 0.02$ & $0.39^{\mathrm{a}} \pm 0.06$ & $16.2^{\mathrm{a}} \pm 1.5$ \\
\hline & & Tilapia & 16 & $0.30^{\mathrm{a}} \pm 0.08$ & $0.66^{\mathrm{a}} \pm 0.07$ & $0.44^{\mathrm{a}} \pm 0.07$ & $17.3^{\mathrm{a}} \pm 1.6$ \\
\hline
\end{tabular}

* Values are given as means \pm Std dev. Means with different superscript letters within a column are significantly different $(\mathrm{P}<0.05)$. The concentration is expressed as $\mathrm{mg} / 100 \mathrm{~g}$ except for mercury which is expressed in $\mu \mathrm{g} / 100 \mathrm{~g}$

\section{Conclusion}

The findings from this study reaffirm that fish are nutritious and can provide important nutrients needed for normal body function and maintenance. The attributes of nutritional value differed significantly between wild and farmed fish. It is important to note that wild fish is rich in most nutrients as compared to fish farmed under the three non-intensive feeding systems studied. Although the wild fish had higher heavy metals as compared to farmed fish, the values were below toxic levels. For farmed fish, the nutritional quality is dependent on the feeding practices. Thus, manipulating the feeding systems might deliver designer fish having preferred quality and nutritional compositions. 


\section{Acknowledgement}

The authors would also like to acknowledge Fish farmers and School of Food and Nutrition Science of the Jomo Kenyatta University of Agriculture and Technology.

\section{References}

Adebayo, I. A., Fapohunda, O. O., \& Ajibade, A. O. (2016). Evaluation of nutritional quality of Clarias gariepinus from selected fish farms in Nigeria. American Journal of Food Science and Nutrition Research, $3(4), 56$.

Agah, H., Leermakers, M., Elskens, M., Fatemi, S. M. R., \& Baeyens, W. (2009). Accumulation of trace metals in the muscle and liver tissues of five fish species from the Persian Gulf. Environmental monitoring and assessment, 157(1-4), 499. https://doi.org/10.1007/s10661-008-0551-8

Ahmed, M. K., Baki, M. A., Islam, M. S., Kundu, G. K., Habibullah-Al-Mamun, M., Sarkar, S. K., \& Hossain, M. M. (2015). Human health risk assessment of heavy metals in tropical fish and shellfish collected from the river Buriganga, Bangladesh. Environmental science and pollution research, 22(20), 15880-15890. https://doi.org/10.1007/s11356-015-4813-z

Alasalvar, C., Taylor, K. D. A., Zubcov, E., Shahidi, F., \& Alexis, M. (2002). Differentiation of cultured and wild sea bass (Dicentrarchus labrax): total lipid content, fatty acid and trace mineral composition. Food chemistry, 79(2), 145-150. https://doi.org/10.1016/S0308-8146(02)00122-X

AOAC. (2006). Official Methods of Analysis of Association of Official Analytical Chemists, (18th edition). Washington D.C.

ATSDR. (2004). Agency for Toxic Substances and Disease Registry, Division of Toxicology, Clifton Road, NE, Atlanta, GA. Retrieved from http://www.atsdr.cdc.

Baroiller, J. F. (2012). Aquaponics: recycling fish excreta. Oreochromis niloticus, the Nile tilapia CIRAD. Retrieved from https://www.cirad.fr/en/news/all-news-items/press-releases/2012/aquaculture

Beto, J. A. (2015). The role of calcium in human aging. Clinical nutrition research, 4(1), 1-8. https://doi.org/10.7762/cnr.2015.4.1.1

Bhouri, A. M., Bouhlel, I., Chouba, L., Hammami, M., El Cafsi, M., \& Chaouch, A. (2010). Total lipid content, fatty acid and mineral compositions of muscles and liver in wild and farmed sea bass (Dicentrarchus labrax). African Journal of Food Science, 4(8), 522-530.

Bosch, A. C., O'Neill, B., Sigge, G. O., Kerwath, S. E., \& Hoffman, L. C. (2016). Heavy metals in marine fish meat and consumer health: a review. Journal of the Science of Food and Agriculture, 96(1), 32-48. https://doi.org/10.1002/jsfa.7360

Butusov, M., \& Jernelöv, A. (2013). Phosphorus in the organic life: cells, tissues, organisms. Phosphorus. Springer, New York, NY. p. 13-17. https://doi.org/10.1007/978-1-4614-6803-5_2

Cox, D. H., \& Karahadian, C. (1998). Evaluation of microbial counts, nucleotide degradation, and sensory attributes of cultured and wild yellow perch (Perca flavescens) during refrigerated storage. Journal of Aquatic Food Product Technology, 7(1), 5-26. https://doi.org/10.1300/J030v07n01_02

Craig, S., Helfrich, L. A., Kuhn, D., \& Schwarz, M. H. (2017). Understanding fish nutrition, feeds, and feeding.

Davidson, J., Barrows, F. T., Kenney, P. B., Good, C., Schroyer, K., \& Summerfelt, S. T. (2016). Effects of feeding a fishmeal-free versus a fishmeal-based diet on post-smolt Atlantic salmon Salmo salar performance, water quality, and waste production in recirculation aquaculture systems. Aquacultural Engineering, 74, 38-51. https://doi.org/10.1016/j.aquaeng.2016.05.004

Demirezen, D., \& Uruç, K. (2006). Comparative study of trace elements in certain fish, meat and meat products. Meat science, 74(2), 255-260. https://doi.org/10.1016/j.meatsci.2006.03.012

El-Zaeem, S. Y., El-Tawil, N. E., \& Amer, T. N. (2012). Effect of direct injection of Shark DNA into skeletal muscles on the productive performance characteristics of Red Tilapia (Oreochromis sp.) fed Different dietary regimes. African Journal of Agricultural Research, 7(16), 2456-2462. https://doi.org/10.5897/AJAR11.2037

FAO. (2010). Nutritional Elements of Food and Agricultural Organization Fish. Rome.

Fuentes, A., Fernández-Segovia, I., Serra, J. A., \& Barat, J. M. (2010). Comparison of wild and cultured sea bass (Dicentrarchus labrax) quality. Food Chemistry, 119(4), 1514-1518. https://doi.org/10.1016/j.foodchem.2009.09.036 
GOA. (2016). African catfish invade Goa. Retrieved from https://itsgoa.com/african-catfish-invade-goa/

González-Fernández, D., Garrido-Pérez, M. C., Nebot-Sanz, E., \& Sales-Márquez, D. (2011). Source and fate of heavy metals in marine sediments from a semi-enclosed deep embayment subjected to severe anthropogenic activities. Water, Air, \& Soil Pollution, 221(1-4), 191. https://doi.org/10.1007/s11270-011-0782-0

Gupta, A., Rai, D. K., Pandey, R. S., \& Sharma, B. (2009). Analysis of some heavy metals in the riverine water, sediments and fish from river Ganges at Allahabad. Environmental monitoring and assessment, 157(1-4), 449. https://doi.org/10.1007/s10661-008-0547-4

Hussain, M., Muhammad, S., Malik, R. N., Khan, M. U., \& Farooq, U. (2014). Status of heavy metal residues in fish species of Pakistan. Reviews of Environmental Contamination and Toxicology volume. Springer, Cham. p. 111-132. https://doi.org/10.1007/978-3-319-04411-8_5

Ishida, H., Suzuno, H., Sugiyama, N., Innami, S., Tadokoro, T., \& Maekawa, A. (2000). Nutritive evaluation on chemical components of leaves, stalks and stems of sweet potatoes (Ipomoea batatas poir). Food Chemistry, 68(3), 359-367. https://doi.org/10.1016/S0308-8146(99)00206-X

Jim, F., Garamumhango, P., \& Musara, C. (2017). Comparative analysis of nutritional value of Oreochromis niloticus (Linnaeus), Nile tilapia, meat from three different ecosystems. Journal of food quality. https://doi.org/10.1155/2017/6714347

Job, B. E., Antai, E. E., Inyang-Etoh, A. P., Otogo, G. A., \& Ezekiel, H. S. (2015). Proximate composition and mineral contents of cultured and wild tilapia (Oreochromis niloticus)(Pisces: Cichlidae)(Linnaeus, 1758). Pakistan Journal of Nutrition, 14(4), 195. https://doi.org/10.3923/pjn.2015.195.200

Jonsson, B., \& Jonsson, N. (2014). Early environment influences later performance in fishes. Journal of Fish Biology, 85(2), 151-188. https://doi.org/10.1111/jfb.12432

Kaile, B., \& Nyirenda, J. (2016). Assessing the bioaccumulative impact of four heavy metals on the endocrine system of Tilapia rendalli fish species in the Kafue River. Annual Research \& Review in Biology, 1-23. https://doi.org/10.9734/ARRB/2016/23132

Kumaran, R., Ravi, V., Gunalan, B., Murugan, S. and Sundramanickam, A. (2012) Estimation of proximate, amino acids, fatty acids and mineral composition of mullet (Mugil cephalus) of Parangipettai, Southeast Coast of India Advances in Applied Science Research. 3 (4): 2015-2019.

Lenntech, B. V. (2013). Recommended daily intake of vitamins and minerals. Lenntech BV Rotterdamseweg, 402.

Lorente-Cebrián, S., Costa, A. G., Navas-Carretero, S., Zabala, M., Martínez, J. A., \& Moreno-Aliaga, M. J. (2013). Role of omega-3 fatty acids in obesity, metabolic syndrome, and cardiovascular diseases: a review of the evidence. Journal of physiology and biochemistry, 69(3), 633-651. https://doi.org/10.1007/s13105-013-0265-4

Mahboob, S., Al-Ghanim, K. A., Al-Balawi, H. F., Al-Misned, F., \& Ahmed, Z. (2019). Study on assessment of proximate composition and meat quality of fresh and stored Clarias gariepinus and Cyprinus carpio. Brazilian Journal of Biology, 79(4), 651-658. https://doi.org/10.1590/1519-6984.187647

Mania, M., Wojciechowska-Mazurek, M., Starska, K., Rebeniak, M., \& Postupolski, J. (2012). Fish and seafood as a source of human exposure to methylmercury. Roczniki Panstwowego Zakladu Higieny, 63(3), 257-264.

McHugh, M. L. (2011). Multiple comparison analysis testing in ANOVA. Biochemia medica: Biochemia medica, 21(3), 203-209. https://doi.org/10.11613/BM.2011.029

Mohanty, B. P., Ganguly, S., Mahanty, A., Mitra, T., Patra, S., Karunakaran, D., \& Dayal, S. (2019). Fish in human health and nutrition. Adv Fish Res, 7, 189-218.

Mohanty, B. P., Sankar, T. V., Ganguly, S., Mahanty, A., Anandan, R., Chakraborty, K., ... Asha, K. K. (2016). Micronutrient composition of 35 food fishes from India and their significance in human nutrition. Biological trace element research, 174(2), 448-458. https://doi.org/10.1007/s12011-016-0714-3

Morrissey, J., \& Guerinot, M. L. (2009). Iron uptake and transport in plants: the good, the bad, and the ionome. Chemical reviews, 109(10), 4553-4567. https://doi.org/10.1021/cr900112r

Moser-Veillon, P. B. (1990). Zinc: consumption patterns and dietary recommendations. Journal of the American Dietetic Association, 90(8), 1089-1093.

Oladipo, I. C., \& Bankole, S. O. (2013). Nutritional and microbial quality of fresh and dried Clarias gariepinus and Oreochromis niloticus. International Journal of Applied Microbiology and Biotechnology Research, 1(1), 
$1-6$.

Perugini, M., Visciano, P., Manera, M., Zaccaroni, A., Olivieri, V., \& Amorena, M. (2014). Heavy metal (As, Cd, $\mathrm{Hg}, \mathrm{Pb}, \mathrm{Cu}, \mathrm{Zn}, \mathrm{Se})$ concentrations in muscle and bone of four commercial fish caught in the central Adriatic Sea, Italy. Environmental monitoring and assessment, 186(4), 2205-2213. https://doi.org/10.1007/s10661-013-3530-7

Pfenning, F., Kurth, T., Meißner, S., Standke, A., Hoppe, M., Zieschang, F., ... Gutzeit, H. O. (2012). The social status of the male Nile tilapia (Oreochromis niloticus) influences testis structure and gene expression. Reproduction, 143(1), 71-84. https://doi.org/10.1530/REP-11-0292

Piero, M. N., Njagi, J. M., Kibiti, C. M., Ngeranwa, J. J. N., Njagi, E. N. M., \& Miriti, P. M. (2012). The role of vitamins and mineral elements in management of type 2 diabetes mellitus: A review. South Asian Journal of Biological Science, 2, 107-115.

Prashanth, L., Kattapagari, K. K., Chitturi, R. T., Baddam, V. R. R., \& Prasad, L. K. (2015). A review on role of essential trace elements in health and disease. Journal of dr. ntr university of health sciences, 4(2), 75. https://doi.org/10.4103/2277-8632.158577

Praveeena, S., PaSula, S., \& Sameera, K. (2013). Trace elements in diabetes mellitus. Journal of clinical and diagnostic research: JCDR, 7(9), 1863.

Pravina, P., Sayaji, D., \& Avinash, M. (2013). Calcium and its role in human body. International Journal of Research in Pharmaceutical and Biomedical Sciences, 4(2), 659-668.

Rani, P. S. C. H. P. D., Kumar, P. V., Rao, K. R., \& Shameem, U. (2016). Seasonal variation of proximate composition of tuna fishes from Visakhapatnam fishing harbor, East coast of India. International Journal of Fisheries and Aquatic Studies, 4(6), 308-313.

Soetan, K. O., Olaiya, C. O., \& Oyewole, O. E. (2010). The importance of mineral elements for humans, domestic animals and plants: A review. African journal of food science, 4(5), 200-222.

Turhan, S., Ustun, N. S., \& Altunkaynak, T. B. (2004). Effect of cooking methods on total and heme iron contents of anchovy (Engraulis encrasicholus). Food Chemistry, 88(2), 169-172. https://doi.org/10.1016/j.foodchem.2004.01.026

USDA. (2010). United State Department of Agriculture, Agricultural Research Service, National Nutrition Data base for standard reference. Release, 23. Nutrition Laboratory.

Wahwua, T. A. T. (1999). Applied Statistics for Scientific Studies. Aba-Nigeria. pp. 129-155.

Whiting, S. J., \& Barabash, W. A. (2006). Dietary reference intakes for the micronutrients: considerations for physical activity. Applied physiology, nutrition, and metabolism, 31(1), 80-85. https://doi.org/10.1139/h05-021

WHO. (2011). Guidelines for drinking-water quality. WHO chronicle, 38(4), 104-8.

WHO. (2015) Micronutrient deficiencies: iron deficiency anaemia. Retrieved from http://www.who.int/nutrition/topics/ida/en/

Wu, X., Cobbina, S. J., Mao, G., Xu, H., Zhang, Z., \& Yang, L. (2016). A review of toxicity and mechanisms of individual and mixtures of heavy metals in the environment. Environmental Science and Pollution Research, 23(9), 8244-8259. https://doi.org/10.1007/s11356-016-6333-X

\section{Copyrights}

Copyright for this article is retained by the author(s), with first publication rights granted to the journal.

This is an open-access article distributed under the terms and conditions of the Creative Commons Attribution license (http://creativecommons.org/licenses/by/4.0/). 